\title{
Critical Multicultural Education: Working at the Intersections of Resistance, Restorative Justice, and Revolutionary Change-Introduction
}

\author{
Christine Clark * and Norma A. Marrun \\ Cultural Studies, International Education, and Multicultural Education (CSIEME), Department of Teaching and \\ Learning, College of Education, University of Nevada, Las Vegas, NV 89154-3001, USA; norma.marrun@unlv.edu \\ * Correspondence: chris.clark.unlv@me.com
}

Received: 14 June 2019; Accepted: 17 June 2019; Published: 18 June 2019

We are pleased to serve as co-editors for this Education Sciences Special Issue focused on Critical Multicultural Education: Working at the Intersections of Resistance, Restorative Justice, and Revolutionary Change. Contributors to this Special Issue are graduates and/or close academic affiliates of the University of Nevada, Las Vegas' doctoral program emphasis in Cultural Studies, International Education, and Multicultural Education, also known as "CSIEME," pronounced phonetically as "See Me."

"See Me" is evocative of the Zulu notion of "Sawubona," which literally translates to, "We see you," but more conceptually conveys intentional collective acknowledgement of everyone's human presence, particularly the value and importance of that presence: "Good to see you," and "Good to be seen." Because the concept of Sawubona, of seeing and being seen, is foundational to the work done in the CSIEME emphasis, we asked contributors to this Special Issue to submit relevant research and praxis articles related to themes that challenge deficit narratives, and reveal and document counterstories, about historically, persistently, and newly minoritized and marginalized communities in the United States-so that members of these communities are "seen." Themes highlighted in the call for articles included, but were not limited to:

1) The persistent failure of teacher education to recruit and retain teacher educators of Color and pre-service teachers of Color and the implications of their absence on the educational experiences of PK-12 students of Color.

2) The persistent failure of educational leadership education and of PK-12 school leaders to listen to and meaningfully engage Black women, and other women of Color, as educational leaders and their critically culturally relevant and responsive educational leadership expertise in U.S. schools.

3) Gay teacher identity development and its impact on the experiences of out and closeted Gay teachers in PK-12 schools that are supportive of or hostile to Lesbian, Gay, Bisexual, Trans, and Queer (LGBTQ) concerns.

4) The manners in White female teacher engagement/non-engagement with especially Black, as well as with Latinx and Indigenous, male students facilitates the gross disproportionate funneling of these students, as well as their female counterparts, into the school-to-prison pipeline.

5) The persistent failure of teacher education to prepare and support critically culturally relevant and responsive teachers, including through professional development and performance review.

6) The long-term implications of the educational experiences of Black students, and other students of Color, who are transracially adopted, racially isolated in schools (from like peers and teachers), experience various forms of identity marginalization (especially through PK-12 curricula), and/or are otherwise systemically minoritized. 
7) The impact of critical multicultural education on the language dispositions of pre- and in-service teachers and their preparedness to work effectively with students, and their families, who speak English differently and/or as a second language.

8) The educational implications of forced and reverse migration on Chicanx, Mexican American, Mexican, and other families, including how children of deported parents use various forms of resistance to educationally navigate on both sides of the U.S.-Mexico border.

9) The manners in which recent immigrant parents of 1.25, 1.5, and 1.75 generation immigrantand U.S.-born children navigate the U.S. education system, and the importance of school- and community-based family engagement initiatives in their successful navigation.

We also asked contributors to the Special Issue to emphasize the use of critical, indigenous [1], and emancipatory research methodology [2] and inquiry methods in challenging deficit narratives [3], and revealing and documenting counterstories [4], about historically, persistently, and newly minoritized and marginalized communities in the United States. More specifically, we asked contributors to situate their research in Critical Race Theory [5], intersectional analysis [6], radical (from the root, grassroots, origins, and beginnings) resistance [7], and realization of restorative, transformative [8], and revolutionary change [9]. The articles included in this Special Issue reflect the contributors' thoughtful attention to the highlighted themes, use of emergent methods, sociopolitical grounding, and fidelity to work for justice.

It is our hope that this Special Issues will serve as a springboard to the development of a CSIEME journal, modeled after the Berkeley Review of Education (BRE), which is an open-access, peer-reviewed journal edited by students from the Graduate School of Education at the University of California, Berkeley. Accordingly, we are using this Special Issue opportunity as a way to move toward launching that journal, with the primary objective of that effort being to provide a space for members of our CSIEME community to learn how journals work and to gain experience preparing their own, and editing others', work for publication. The exemplary recent, current, and on-going work included in this Special Issue will go a long way in facilitating our subsequent launch of a CSIEME journal. We are grateful to Education Sciences for providing us this opportunity.

Author Contributions: Conceptualization, C.C. and N.A.M.; methodology, not applicable; software, not applicable; validation, C.C. and N.A.M.; formal analysis, C.C. and N.A.M.; investigation, not applicable; resources, not applicable; data curation, not applicable; writing—original draft preparation, C.C. and N.A.M.; writing-review and editing, C.C. and N.A.M.; visualization, C.C. and N.A.M.; supervision, C.C. and N.A.M.; project administration, C.C. and N.A.M.; funding acquisition, not applicable.

Funding: This research received no external funding.

Conflicts of Interest: The authors declare no conflict of interest.

\section{References}

1. Smith, L.T. Decolonizing Methodologies: Research and Indigenous Peoples, 2nd ed.; Zed Books: New York, NY, USA, 2012.

2. Denzin, N.; Lincoln, Y.; Smith, L.T. Handbook of Critical and Indigenous Methodologies; Sage: London, UK, 2008.

3. Valencia, R.R. (Ed.) The Evolution of Deficit Thinking: Educational thought and Practice; Routledge: New York, NY, USA, 1997.

4. Solórzano, D.; Yosso, T. Critical race methodology: Counter-storytelling as an analytical framework for education research. Q. I. 2002, 8, 23-44.

5. Ladson-Billings, G. Just what is critical race theory and what's it doing in a nice field like education? Int. J. Qual. Stud. Educ. 1998, 11, 7-24. [CrossRef]

6. Crenshaw, K. Mapping the margins: Intersectionality, identity politics, and violence against women of color. Stanford Law Rev. 1991, 43, 1241-1299. [CrossRef]

7. Giroux, H. Theories of reproduction and resistance in the new sociology of education: A critical analysis. Harv. Educ. Rev. 1983, 53, 257-293. [CrossRef] 
8. hooks, b. Teaching to Transgress; Routledge: New York, NY, USA, 1994.

9. Freire, P. Pedagogy of the Oppressed; Seabury Press: New York, NY, USA, 1970.

(C) 2019 by the authors. Licensee MDPI, Basel, Switzerland. This article is an open access article distributed under the terms and conditions of the Creative Commons Attribution (CC BY) license (http://creativecommons.org/licenses/by/4.0/). 